\title{
Dignity, body parts and the actio iniuriarum: a novel solution to a common (law) problem?
}

\author{
BROWN, J.
}

2019

This article has been accepted for publication in a revised form in Cambridge Quarterly of Healthcare Ethics https://doi.org/10.1017/S0963180119000446. This version is free to view and download for private research and study only. Not for re-distribution, re-sale or use in derivative works. (c) copyright holder. 


\section{Dignity, Body Parts and the Actio Iniuriarum: A Novel Solution to a Common (Law) Problem?*}

Jonathan Brown* 


\section{Introduction}

In issue 4 of the $23^{\text {rd }}$ volume of this journal, Charles Foster published a critical piece on the topic of Dignity and the Ownership and Use of Body Parts, arguing that property-based models of the ownership of human body parts are as ubiquitous as they are inadequate. ${ }^{1}$ The notion of 'human dignity', Foster argues (therein and in some of his earlier work), ${ }^{2}$ serves as a better candidate than its competitors for the role of moral guide in disputes pertaining to body parts which have been severed from their original subject. This argument is posited notwithstanding the fact (that Foster himself recognises) that dignity is often seen as a 'hopelessly amorphous',3 'vacuous concept' which should be 'discarded as a potential foundation for rights claims, unless and until its source, nature, relevance and meaning are determined' ${ }^{4}$

The present piece does not purport to definitively determine the source, nature, relevance and meaning of the broad concept of 'dignity' as it exists in legal or ethical thought. Rather, it sets out simply to illustrate that in the mixed legal systems of Scotland and South Africa, legal claims which are predicated on the occurrence of some infringement of human dignity have been raised (and have the potential to be raised), pressed, and ultimately vindicated by the courts in those jurisdictions. ${ }^{5}$ Such claims have been predicated on the basis of the actio iniuriarum, a legal mechanism which has been neglected by Scots jurisprudence for some time, ${ }^{6}$ in spite of its unquestioned reception into that legal system, ${ }^{7}$ but which fundamentally forms one of the three 'pillars' of the South African law of obligations alongside Aquilian liability and the action for pain and suffering. ${ }^{8}$

In essence, the actio iniuriarum serves to compensate those persons who have suffered some hurt - be that hurt emotional, physical or fiscal - at the hands of another. In Roman law, the etymologically complex term iniuria could refer to a number of distinct wrongs - indeed, for that very reason the term may be familiar to Anglo-American lawyers due to its place within 
the Aquilian damnum injuria datum - but in the sense of the specific delict it referred to any contumelious attack on the dignity of a freeman. ${ }^{9}$ Modern scholarship in Civil law and Civilianinfluence countries has developed an understanding of a number of taxonomically distinct 'personality rights' (though Scots law, in this area, remains 'a thing of shreds and patches'), ${ }^{10}$ but 'at a high level of generality, it would probably not be controversial to say that all iniuriae were offences against dignity... dignitas is assailed, not when certain outcomes are made out, but precisely by the defendant's mind-attitude of disregarding the other party's status ..11

With the above in mind, this article seeks to establish that those scenarios set forth by Foster in his piece are, as that author claims, matters which raise concerns about human dignity (understood broadly) and that in any legal system which recognises a need to expressly protect human dignity where it has been infringed, a mechanism akin to the actio iniuriarum may be - and indeed should be - utilised to provide recompense to aggrieved parties. In an earlier work, Foster claimed that 'there are some situations in medical ethics and in bioethics with which existing analytical tools are wholly unable to deal'. ${ }^{12}$ This article highlights the inaccuracy of this statement; the required analytical tools to deal with difficulties of the kind that Foster describes are, indeed, extant, but they are to be found within the realm of 'oxymoronic comparative law', ${ }^{13}$ rather in any one Common law legal system.

\section{Dignity and the Actio Iniuriarum}

In the words of Professor Laurie, 'a dictionary description [of dignity] is as good as any other because dignity has eluded successful description since its proliferation in legal instruments and declarations on human rights in the post-Second World War Era'.14 Nevertheless, the mercurial nature of the term 'dignity' has not prevented the actio iniuriarum from operating as an effective and sophisticated legal mechanism which expressly affords remedy to those claiming affront to dignity in Romanistic legal systems. ${ }^{15}$ 
'Dignity' does not simply exist as an unexpressed undercurrent which silently informs the operation of the actio iniuriarum; in addition to existing at the core of the action itself, ${ }^{16}$ one’s interest in one's dignity is manifestly recognised as an essential personality right which is worthy of protection. The Roman jurist Ulpian identified three interests against which the delict of iniuria could be committed - corpus (the body), fama (reputation) and dignitas (dignity). ${ }^{17}$ This triad of non-patrimonial interests was adopted and popularised by the work of the Dutch jurist Voet ${ }^{18}$ which greatly informed the development of jurisprudence in Scotland and South Africa, as well as the Civil law tradition more widely. The influence of this work in the Common law tradition, however, was more limited. Anglo-American law recognises only the first and second of the trio as meriting legal protection, offering protection in respect of corpus by way of torts such as assault and battery, and protection to fama by way of the torts of slander and libel. ${ }^{19}$ Dignitas is not expressly afforded protection. ${ }^{20}$ In Civilian and Civilianinfluenced legal thought, however, the term is now understood to exist as a nomen collectivum; a general clause:

“Although one may identify... corpus and fama as independent personality rights with a more or less fixed meaning, the same cannot be said of dignitas... Dignitas was a collective term for all personality interests, excluding corpus and fama, which in Roman law had not yet been clearly distinguished and independently delimited".21

Dignitas, within the context of the actio iniuriarum, can consequently be described as 'an all-embracing interest, capable of extending so as to protect a wide range of rights'.22 Thus, though it can certainly be said that dignitas is 'the most problematic' of the trio, it also remains 'at once the most interesting' of the three protected interests. ${ }^{23}$ In modern South African law, it has been determined that dignity - and infringements thereof - is to be both objectively and subjective assessed; the concept consequently encompasses both an individual's own subjective feelings of self-worth along with objectively determined features 
such as their freedom, autonomy and equality with other legal subjects. ${ }^{24}$ The recognition of dignity as a protected legal interest is the recognition of 'the intrinsic worth of human beings' which necessitates that such subjects are regarded, by law, as 'entitled to be treated as worthy of respect or concern. ' ${ }^{25}$ Such is consistent with Laurie's chosen dictionary definition of the term, which describes 'dignity' as 'the state or quality of being worthy of respect'. ${ }^{26}$

In a sense which remains general, yet is still specific enough to permit the pursuit of remedies in respect of infringement of dignity in the courts, 'dignity' may therefore be understood as a non-patrimonial interest entitling all legal persons to be treated, in all circumstances, with respect. This interest is inviolable, but with that said all persons may nevertheless waive their right to raise an action in respect of a breach of their dignity by plain exercise of their basic autonomy. ${ }^{27}$ This conception of dignity, therefore, treats the concept of autonomy as a partner, rather than a competitor.

From the above definition, it follows that 'infringing a person's dignity means insulting that person'. ${ }^{28}$ To do such is to commit the delict of iniuria. As shall be demonstrated in the next section, as at the core of each of Foster's three presented scenarios is some insult or affront effected against either a specific human being, or humanity in general. On this basis, it can be empirically demonstrated that Foster's assertion that the language of dignity could better serve to describe the nature of the wrongdoing, where the language of 'property' could not, is essentially correct.

\section{Foster's Three Scenarios}

In his piece for this journal, Foster set out three examples of occasions in which a legal model which conceptualises human biological material as ‘property' would either do only a 'workmanlike job' at best, or fail utterly to capture the essence of the issue at hand at worst. ${ }^{29}$ Foster had previously espoused the three scenarios in his earlier work published in the Journal 
of Medical Ethics (JME); ${ }^{30}$ the issues at hand are identical in the scenarios presented in both publications, but the text from the CQHE publication is reproduced below:

1. “A child's heart, retained for the purposes of medical research: The child died of a disease being studied at the institute that has retained it. Its heart, which is particularly useful to the researchers, was removed at post-mortem without the knowledge of the parents. The rest of the body was returned and buried. The researchers say that they did not seek the parents’ permission because they knew that it would have been refused. They are unrepentant, asserting that the value of their research to future children trumps any ethical quibbles about parental consent.

2. A human ear ashtray: Medical students steal an ear from the cadaver they are dissecting. Back at their student squat, they use it as an ashtray. The cadaver was donated for the purposes of medical education, and the donor (the person whose body it is) would have been outraged at this misuse.

3. A human head football: Children play football in the street with the head of an unknown person, with no living relatives, dug out by a dog from a mediaeval cemetery."31

Foster is right to note that a property-based legal model may potentially offer some remedy in respect of the wrongdoing which occurred in some of these hypothetical situations, but that equally the language of property seems utterly inappropriate in each of these scenarios. The actions of the purported wrongdoers in each of the three fictitious cases cannot be regarded as morally equivalent to plain theft or trespass. Indeed, even if they were so, Common law jurisdictions would find it difficult to offer remedy under the heading of 'property' in each of these circumstances, given the longstanding rule precluding 'property in a corpse'32 (which has, itself, been extended to cover all human biological material more widely). ${ }^{33}$ 
Having made his case that the language of property is inadequate to describe the problems raised in each of the three scenarios, Foster goes on to make a strong case that, in each of the three cases, the language of 'dignity’ ought to be preferred as a means of describing each of these wrongs, though he concedes that 'dignity is easier to recognise than define'.34 This statement is true not only in respect of the philosophical notion, which has attracted a copious amount of comment from ethical thinkers and philosophers, ${ }^{35}$ but also of the legal conception of 'dignity' within the context of the actio iniuriarum. Since the core of 'dignity', as a specific personality interest, is the right to be treated with respect and there are a potentially infinite number of ways in which disrespect may be manifested, ${ }^{36}$ it should follow that an infringement of dignity should be easier to detect that to define. Such difficulty has not ${ }^{37}$ and should not present difficulties to those who wish to seek remedy in respect of infringement of dignity.

Accordingly, in spite of the difficulties in defining and delimiting 'dignity' within the law, it can be shown that each of the three scenarios set out by Foster would give rise to actionable iniuriae in any jurisdiction which recognises the existence of such a concept. Indeed, as is elucidated below, there is (comparatively) recent Scottish case law which demonstrates that the first of the three scenarios represents a clear case of iniuria and there exists South African jurisprudence which indicates that the third, though dealt with in terms of the criminal, rather than civil, law, may also amount to an illegal infringement of dignity.

The second of the three scenarios may also be conceptualised as an instance of iniuria. In Pitmedden's $17^{\text {th }}$ century treatise on 'Mutilation and Demembration', there is reference to a debate amongst the Civilian ius commune scholars as to whether or not the severing of a limb from a dead body ought to be categorised as 'demembration' (a specific sub-category of iniuria). ${ }^{38}$ Thus, it is possible to make the case that Foster is right to suggest that the language of dignity is instructive in dealing with all three hypothetical cases. 
Considering each of Foster's scenarios in turn, it is plain that the first of the three is analogous to $A B v$ Leeds Teaching Hospital. ${ }^{39}$ This case concerned the removal of organs from deceased children without parental authorisation. In response to this, the parents raised a group action in respect of psychiatric injury. The claim was based on the grounds that the organs of the children were removed from their bodies, retained by the hospital and subsequently disposed of by the hospital with neither the knowledge nor consent of the parents, as ss.1-2 of the Human Tissue Act 1961 (the Human Tissue Act 2004 having not yet been enacted) required.

In this case, it was ultimately held that since 'to dissect and fix an organ from a child's body requires work and a great deal of skill, the more so in the case of a very small baby', and since there exists, in English law, an exception to the 'no property rule' whereby if, by exercise of 'human work or skill', the biological material could be said to have taken on the character of 'property', ${ }^{40}$ it necessarily followed that the organs of the children were to be considered 'property' for the purposes of law. This did not allow the parents of the deceased children to claim any legal remedy, however. By operation of the 'human work or skill rule', the individual who carries out the necessary act of human work or skill acquires ownership of the nova species - the body or body part that is 'worked' on. Accordingly, it was held that the hospital were to be regarded, in law, as the 'owners' of the organs once its employees conducted the necessary 'work' on the bodies. The plaintiffs in $A B$ were thus unable claim remedy in either property law or in tort law. Indeed, it was because they lacked ownership of their children's organs, combined with the absence of any nominate tort concerned with wrongful interference with the body, that the plaintiffs had no remedy in law at all. This state of affairs solidly demonstrates the veracity of Foster's averment that property law is inadequate in cases of this kind. Even in instances in which human biological material is recognised as property, there is no guarantee 
that the individuals who have the closest emotional connection to the material could claim ownership of it.

In Scotland, the outcome of a case which turned on similar facts to $A B$ was decidedly different. As a result of Scotland's institutional connection to the actio iniuriarum, it was decided, in Stevens $v$ Yorkhill NHS Trust, ${ }^{41}$ that the actions of a group of medical professionals who retained the brain of a stillborn infant without parental authorisation were wrongful as they amounted to the delict of iniuria. Accordingly, compensation was payable to the parents of the deceased child by means of the actio iniuriarum. In the words of Temporary Judge Macaulay QC, "Scots law recognises as a legal wrong for which damages by way of solatium can be claimed the unauthorised removal and retention of organs from a dead body. The Scottish cases suggest that the true juridical basis for this type of claim lies in the actio injuriarium. English law, with its different legal history may not recognise the existence of such a wrong, but that does not impact upon the position in Scotland.”

The Court of Session was able to wholly avoid the issue of 'property' in the body or organs of the child in Stevens since the true nature of the dispute was not regarded as proprietary at all. Following from three earlier cases concerning unauthorised post-mortems, ${ }^{42}$ Macaulay noted that "the judges [in these cases] considered that, in the circumstances, the unauthorised post mortems and the unauthorised removal and retention of body parts, disclosed such an insensitivity to the feelings of near relatives following upon the death of a loved one, that such conduct constituted an affront to their dignity as relatives of the deceased so as to justify being classified as a civil wrong in which damages by way of solatium could be claimed”.

The judgment of the court in Stevens was in line with the findings of the 2003 McLean report, ${ }^{43}$ which found that the fundamental objection put forth by families in respect of postmortem practice was the 'insult' effected by the retention of organs. Though the report did not 
deign to discuss the delict of iniuria, it nevertheless sought to 'clarify and reinforce the very real interests that parents have in their children, even after their death' ${ }^{44}$ Like Foster, ${ }^{45}$ it sought to utilise Article 8 of the European Convention on Human Rights to realise this purpose. In 2005, however, Professor Whitty noted that the "word "insult" matches exactly the affront which triggers the actio iniuriarum'. ${ }^{46}$ Consequently, it was suggested that if one were to substitute 'the concept of "the dignity" of the family unit' for that of 'privacy', then 'one can see that the Report is striving to create, from the ECHR and non-legal materials, established legal principles which already do underlie the existing Scots private law right of action for solatium for wounded feelings arising from affront' ${ }^{47}$

In holding that the conduct in Stevens amounted to iniuria, the Outer House ensured the provision of a simpler, and consequently more satisfactory, remedial approach to issues of this kind than that suggested in the McLean report. It was able to do so by dint of the existence of 'dignity' as a protected legal interest in Scots law. Accordingly, it can be demonstrated that Foster is not only right to suggest that the language of dignity would be best placed to describe the nature of the wrong which occurred in the first of his three examples, since the 'insult' impinging the parent's dignity may be said to be the crux of the wrongdoing, but also that there exists a legal taxonomy which practically serves to not only offer remedy, but to do so in the terms which Foster describes.

As noted in regard to the second of the hypothetical scenarios, Lord Pitmedden specifically considered an example akin to that which Foster described. By the time of Pitmedden's writing, iniuria existed within the taxonomy of Scots law as a high-level category which was itself divisible into 'second-level' and tertiary sub-categories. ${ }^{48}$ Among the secondlevel categories were the subdivisions iniuria realis - which pertained to iniuriae committed by way of physical acts - and iniuria verbalis - which pertained to iniuriae effected by way of words. These sub-categories themselves could be sub-divided into third-level (tertiary) 
categories; thus, mutilation (severing body parts from a person) and demembration (permanently crippling the limb(s) of a person) - the subjects which Pitmedden treated in his treatise - were taxonomically considered to be specific sub-categories of iniuria realis.

In the course of his work, Pitmedden considered whether 'a man may be punished as a demembrator who cuts off a member of a dead man out of a design to disgrace it' ${ }^{49}$ Pitmedden himself took the view that such a man could not be so regarded, drawing on the authority of the Italian jurist Prospero Farinacci, although it was nevertheless noted that the jurists of the ius commune were not of one mind in respect of this question. Pitmedden himself recognised that the Spaniard Francisco Suárez was of the view that such a man ought to be punished for demembration due to the malice demonstrated in the commission of such an act.

Whether or not one may say that the dignity of the corpse is infringed by the severing of a body part from it, it is clear that, from the logic presented by Macaulay in respect of the Scottish unauthorised post-mortem cases, ${ }^{50}$ such an act could be regarded as displaying such insensitivity towards the family of the deceased that it ought to permit them remedy in respect of the affront to their dignity. This would be consistent with the position set out by Foster and such would provide remedy for the occurrence of an obvious - if nebulous and indefinable act of wrongdoing. ${ }^{51}$ The potential for the actio iniuriarum to remedy wrongs of this kind, in language which adequately captures the nature of the wrongdoing, is consequently apparent and is, indeed, confirmed by the Roman sources ${ }^{52}$ and Scottish institutional writers. ${ }^{53}$ In effect, though the dead may not be able to lay claim to any interest in dignity, the surviving heirs of a deceased person do retain an interest in protecting the dignity interests of their forbearers.

The benefit of the recognition of iniuria as a legal wrong - and thus, by association, of dignity as a legal interest - in cases of this kind can also be seen by contrasting the legal consequences of the mistreatment of the cadaver of Habiba Mohammed in England with the 
outcomes of the South African cases of $R v$ Letoka $^{54}$ and $R v$ Sephuma. ${ }^{55}$ In 2003, the corpse of Ms. Mohammed was desecrated by an unknown individual or group. In obvious contempt of her Muslim faith, Ms. Mohammed's body was covered in rashers of bacon as it lay in the morgue. In spite of the clear insult directed towards Ms. Mohammed's family and the wider Muslim community, no civil or criminal remedy was available under English law as the desecration 'could not be 'tied' to any particular crime'. ${ }^{56}$ By contrast, in Letoka and Sephuma, which each involved the mutilation of cadavers, the South African courts held that the violation of a corpse was an abomination which effects 'a gross outrage to the feelings and sensibilities of the relatives of the child [i.e., the deceased]. ${ }^{57}$ Such outrage, as indicated above, could be remedied by means of a claim of iniuria and the provision of remedy in such circumstances could be justified by reference to the indignity inflicted on the family of the deceased. ${ }^{58}$

Turning to the third of Foster's scenarios, it is submitted that the insensitivity displayed by the boys in this hypothetical is such that, if the deceased were to have any family, the actio iniuriarum could provide them with a remedy. In the absence of family, however, it would appear that there is no civil remedy, though only because no one could be said to hold the requisite locus standi to raise an actio iniuriarum; the actions of the boys are still evidently wrongful. Thus, it is notable that in South Africa iniuria may amount to criminal conduct, as well as a civil wrong. ${ }^{59}$ The essence of crimen iniuria is practically analogous to the civil conceptualisation of iniuria within South African law, ${ }^{60}$ although it has been said that the affront effected must be 'serious' in order to merit criminal prosecution. ${ }^{61}$

In a 2007 article, Christison and Hoctor made the case that unwarranted interference with cadavers would amount to crimen iniuria ${ }^{62}$ Ultimately, they concluded that 'although the dead are incapable of enforcing the right to dignity (and in a technical legal sense, of possessing it) it is submitted that society as a whole has an interest in the preservation of dead persons' dignity and the state a role as the custodian of this right'. ${ }^{63}$ Such is consistent with 
Foster's claim that dignity serves as the best candidate to describe the wrongdoing present in the third scenario and such clearly illustrates a means by which the law may be used to protect societal interests in human dignity. The question for policy-makers is whether or not such conduct merits criminal sanction; whether or not it is appropriate to transplant the civil law framework underpinning the actio iniuriarum to the criminal law is ultimately beyond the scope of this article. ${ }^{64}$

Though Scotland does not recognise the crimen iniuria, Scottish criminal law nevertheless provides a means of prosecuting conduct of the kind described in Foster's third scenario. In 2004, a group of Edinburgh-based boys were convicted of the crime of violation of sepulchres after they broke into the tomb of the Scots jurist Sir George MacKenzie and thereafter severed and carried off his head before 'playing' with it in the graveyard. ${ }^{65} \mathrm{~A}$ consideration of the Roman crimen violati sepulcri (the ancestor of the modern Scottish crime) specifically illustrates that the rationale for the Scots crime is the affront to human dignity effected by the interference with a corpse which has been reverentially buried. ${ }^{66}$

Like its Scottish successor, the Roman crimen violati sepulcri was a penal action which could be raised in any instance in which a grave was disturbed in some manner or another. Significant for the purposes of the present discussion, the crimen violati sepulcri was an actio popularis, meaning that if an action in response to interference with a grave-site was not raised by one with an interest in the grave, then any Roman citizen could raise the action. ${ }^{67}$ Violation of sepulchre was thus regarded by the Romans as so offensive to public mores that even in an age of primarily private penal actions, it was deemed to be a wrong committed against the public as a whole. The law relating to the crimen violati sepulcri is thus instructive in respect of the third of Foster's posited scenarios; a flexible criminal law action grounded in the recognition of dignity has the potential to allow for specific criminal liability to attach in situations in which there is gross abuse of a previously interred cadaver. 
From the above, it is clear that the legal recognition of iniuria, as it existed in Roman law and as it presently exists in Scotland and South Africa, has the potential to provide legal remedies to those who have been affronted by conduct such as that presented in Foster's three scenarios and to do so utilising the language which Foster holds to be most appropriate in such cases. It has consequently been demonstrated that there exists a practical legal framework which can - and does - specifically serve to protect interests in human dignity. From this, though it has been argued that 'dignity' is an utterly useless concept, it can also be demonstrated that dignity is a useful construct which can be - and should be - used by lawyers and ethicists in novel or difficult cases concerning human biological material. This is so even in spite of the ultimately mercurial or nebulous nature of the word itself.

\section{Lessons from the Actio Iniuriarum?}

The salient point to be drawn from the above analysis is the fact that 'dignity' does not need to be burdened with a restrictive definition in order to act as an effective remedy in respect of wrongdoing. Indeed, the flexibility of the term is an asset. The law can serve to offer restitution to those who have been affronted by the actions of another, even if is difficult to describe the nature of the wrongdoing with absolute precision. By means of a mechanism such as the actio iniuriarum, any sufficiently disrespectful conduct which effects some affront to human dignity may grant remedy to the affronted party: Speaking of the actio iniuriarum as it existed in Roman law, Descheemaeker and Scott noted that 'as long as the wrongdoer's purpose was to bring his victim into disrepute, his conduct - whatever it was - was potentially actionable ${ }^{\text {68 }}{ }^{6}$ Within the terms of the dual subjective/objective test for infringement of dignity, it would appear that this remains the case in Scots and South African law today.

Thus, accepting the premise that Foster's thesis is correct and that certain circumstances - particularly those concerning the regulation of human tissue, but certainly other aspects of 
medical practice - give rise to ethical problems which are best described using the language of dignity, it can further be demonstrated that such circumstances can, in fact, be regulated by an action which makes open and unashamed use of the language of dignity if the taxonomy of the actio iniuriarum is taken as a model. Indeed, it has been demonstrated that this has been the case within two mixed jurisdictions which have been heavily influenced by the Common law tradition, but only by dint of the Civilian roots of those jurisdictions. Consequently, the question of the extent to which the Scottish and South African experience may translate into the Common law remains open.

\section{Iniuria: Instructive For Common Lawyers?}

Nothing within the Common law tradition can be regarded as equivalent to the actio iniuriarum. The action is purely a product of Civilian jurisprudence. In spite of this, it is submitted that jurists and ethicists from the Common law world would do well to consider the nature and operation of the concept as such a consideration could serve to provide answers to, among other things, many of the problems presently identified with Anglo-American law in respect of the ownership and use of body parts.

This submission is substantiated by two additional points: Firstly, the actio iniuriarum now finds use not in purely Civilian legal systems, but rather in mixed jurisdictions which possess close ties to English law, and so just as Scots and South African lawyers may occasionally look to England for guidance in dealing with 'novel' legal problems, so too should it be open for Common lawyers to look to these jurisdictions for guidance when they are faced with such issues. ${ }^{69}$ Secondly it is noted that, as Descheemaeker and Scott persuasively argued in their collection on Iniuria and the Common Law, so-called 'oxymoronic comparative law' can, 'when the two terms of the oxymoron are properly chosen', lead to a stimulating and fruitful outcome. ${ }^{70}$ As those authors - and the collection of contributors to their text - establish in that 
study, and as they had previously established in the 2011 seminar on the subject held at All Souls College, Oxford, an oxymoronic comparison of the place of iniuria in systems which have allowed it to flourish, those which have neglected it and those which never recognised the concept to begin with can be very useful indeed.

Perhaps the strongest argument in favour of the importation, into the Common law, of some mechanism to protect dignity is the fact that an iniuria-like mechanism was already introduced into English law by way of the Protection from Harassment Act $1997 .{ }^{71}$ Even in the complete absence of a common law equivalent to the Roman conception of iniuria, it was evidently felt, by Parliament, that a specific tort akin to this delict was desirable within English law. In Scotland, wherein the actio iniuriarum has been badly mistreated, it has nevertheless been noted that 'there will always be occasions when judges will seem to protect one party from being held up to hatred, contempt or ridicule by another, and that however much the actio iniuriarum may be suppressed, it is liable only to appear elsewhere in the law' ${ }^{72}$ The veracity of this statement may be inferred from the fact that the civil element of the Protection from Harassment Act 1997 was extended to Scotland, functionally duplicating an action which was already available by way of the common law. Likewise, in Germany, where the actio iniuriarum was thrown out by the by the front door', the action nevertheless 'managed to sneak in through the back window' as a result of the recognition of an allgemeines Persönlichkeitsrecht - a general personality right introduced by the Basic Law and later expanded to functionally serve the same purposes as the actio iniuriarum. ${ }^{73}$

Accordingly, it is plainly demonstrable that a jurisdiction which enjoys no foundational connection to the action found it necessary to introduce an analogue to it by statute, a jurisdiction which neglected its institutional connection to the action saw fit to functionally duplicate it and a jurisdiction which, at one time, deigned to dispose of the action entirely nonetheless found it necessary to allow the action to recrudesce. This, it is submitted, illustrates 
both the underlying, yet fundamental, need for the law to recognise and protect human dignity in order to effect just judicial outcomes (broadly), as well as the desirability of a mechanism akin to the actio iniuriarum in any given legal system (specifically).

\section{Conclusion}

Ultimately, it is apparent that in spite of the fact that dignity is a much-maligned notion, it has nevertheless proven itself to be an effective doctrinal tool to allow for remedial claims in Scottish and South African law. More than this, it is apparent that the 'difficult' scenarios set out by Foster in his 2014 pieces are demonstrably examples of iniuria and that, as the concept of 'dignity' lies at the core of the actio iniuriarum, there presently exists a framework which has the potential to allow for disputes of this kind to be resolved utilising the language of dignity.

This extant framework does not require that the scope of 'dignity' be universally and unequivocally determined; indeed, it can be said that it is the flexibility of the term 'dignity' itself which has allowed the actio iniuriarum to operate as an effective legal mechanism. It is true that infringements of dignity are easier to detect than to define and so the nature of the actio iniuriarum as an action which serves to provide remedy to those who have suffered from (potentially) any wrongful conduct ought to be regarded as an asset, rather than a liability.

Though the actio iniuriarum is a product of the Roman legal tradition, with no common law counterpart in the Anglo-American legal world, the existence of the action within Scots and South African law suggests that it has the potential to be instructive in cases which arise in wholly Common law jurisdictions. Indeed, the need for some mechanism akin to the actio iniuriarum has already been implicitly recognised by English legislators, given that the Protection from Harassment Act 1997 functionally served to introduce an analogue to the action into the law of England and Wales. If, indeed, it is desirable to treat the core of legal and 
ethical disputes relating to human biological material, or the human body itself, as human dignity, then a comparative analysis of an action which already has done so - and has the potential to continue doing so - provides the best possible starting point in this debate. Accordingly, it is hoped that this piece shall not be the last word on the potential for the actio iniuriarum to influence medical jurisprudence in mixed and Common law jurisdictions, but rather that it should serve to provoke further discussion.

\footnotetext{
${ }^{1}$ Charles Foster, Dignity and the Ownership and Use of Body Parts, [2014] Cambridge Quarterly of Healthcare Ethics Vol.23, Issue 4, 417

${ }^{2}$ Charles Foster, Dignity and the Use of Body Parts, [2014] Journal of Medical Ethics 44

${ }^{3}$ See note 2, Foster, 2014, p.45

${ }^{4}$ Mirko Bagaric and James Allan, The Vacuous Concept of Dignity, [2006] Journal of Human Rights 257, p.269

${ }^{5}$ For Scotland, see Stevens $v$ Yorkhill NHS Trust 2006 S.L.T. 889; for South Africa, see Le Roux v Dey [2011] ZACC4

${ }^{6}$ Kenneth McKenzie Norrie, The Actio Iniuriarum in Scots Law: Romantic Romanism, or Tool for Today? in Eric Descheemaeker and Helen Scott, Iniuria and the Common Law, (Oxford and Portland, Oregon: Hart, 2013)

${ }^{7}$ See Jonathan Brown, Revenge Porn and the Actio Iniuriarum: Using 'Old Law' to Solve 'New Problems', [2018] Leg. Stud. 1-15 https://doi.org/10.1017/lst.2018.8

${ }^{8}$ J. Neethling, J. M Potgieter and P. J Visser, Law of Delict, (4 ${ }^{\text {th }}$ Edition) (Durban: Butterworths, 2001) p.8

${ }^{9}$ R. W Leage, Leage's Roman Law, (London: MacMillan and Co., 1909), p.417; Dig. 47.10.2

${ }^{10}$ Elspeth Christie Reid, Personality, Confidentiality and Privacy in Scots Law, (W. Green, 2010) para.1.02

${ }^{11}$ Eric Descheemaeker and Helen Scott, Iniuria and the Common Law, (Oxford and Portland, Oregon: Hart, 2013), p.13

${ }^{12}$ Charles Foster, Human Dignity in Bioethics and Law, (Hart Publishing, 2011), p.1

${ }^{13}$ As defined by Descheemaeker and Scott: See Eric Descheemaeker and Helen Scott, Iniuria and the Common Law, (Oxford and Portland, Oregon: Hart, 2013), p.1

${ }^{14}$ Graeme Laurie, Personality, Privacy and Autonomy in Medical Law, Niall R. Whitty and Reinhard Zimmerman, Rights of Personality in Scots Law: A Comparative Perspective, (Dundee: DUP, 2009), pp.454-455

${ }^{15}$ Lord Kilbrandon, The Law of Privacy in Scotland, [1971] Cambrian Law Review 31, p.38

${ }^{16}$ Per Justinian's Digest, the action serves to remedy 'every iniuria which is inflicted against the person or relates to one's dignity or involves disgrace' - Dig. 47.10.1.2

${ }^{17}$ Dig. 47.10.1.2

${ }^{18}$ Voet, De Injuriis, IV, 4, 58;

${ }^{19}$ Bede Harris, A Roman Law Solution to an Eternal Problem: A Proposed New Dignitary Tort to Remedy Sexual Harassment, [2017] Alternative Law Journal 200, p.202

${ }^{20}$ See David Ibbetson, A Historical Introduction to the Law of Obligations, (Oxford: OUP, 1999), pp.14-17

${ }^{21}$ See note 8, Law of Delict, p.14

${ }^{22}$ See note 19 Harris, 2017, p.202

${ }^{23}$ Niall R. Whitty, Overview of Rights of Personality in Scots Law, in Niall R. Whitty and Reinhard Zimmerman, Rights of Personality in Scots Law: A Comparative Perspective, (Dundee: DUP, 2009), p.159

${ }^{24}$ Jonathan Burchell, Personality Rights in South-Africa: Re-Affirming Dignity, in Niall R. Whitty and Reinhard Zimmerman, Rights of Personality in Scots Law: A Comparative Perspective, (Dundee: DUP, 2009)

${ }^{25}$ Per Mr Justice O’Regan in S v Makwanyane 1995 (3) SA 391 (CC), p.328

${ }^{26}$ The New Oxford Dictionary of English (Oxford: OUP, 2001)
} 
${ }^{27}$ I.e., one may not feel subjectively affronted by objectively wrongful conduct.

${ }^{28}$ See note 23, Whitty, 2009, p.160

${ }^{29}$ See note 1, Foster, 2014, p.418

${ }^{30}$ See note 2, Foster, 2014, p.45

${ }^{31}$ See note 1, Foster, 2014, p.418

${ }^{32}$ The principle can supposedly be traced back to Coke, but it is doubtful that he ever intended to establish this rule. Nevertheless, in the case of $R v$ Sharpe [1857] it was established that a dead body could not be the object of theft in criminal law by dint of this principle and in Williams $v$ Williams (1882) it was accepted that the 'no property' rule was operative within English civil law as well.

${ }^{33}$ See Jesse Wall, Being and Owning, (Oxford: OUP, 2015), p.1

${ }^{34}$ See note 1, Foster, 2014, p.421

${ }^{35}$ See Deryck Beyleveld, Human Dignity in Bioethics and Biolaw, (Oxford: OUP, 2001), passim; Doris Schroeder and Abol-Hassan Bani-Sadr, Dignity in the 21st Century Middle East and West, (Springer, 2017), passim.

${ }^{36}$ Such was recognised by the Scottish Institutional writer Viscount Stair, who lamented 'yea, there be innumerable such acts which the malice and cruelty of men can invent': Stair, Institutes, IV, 40, 26

${ }^{37}$ See note 5, Le Roux v Dey

${ }^{38}$ Sir Alexander Seton, Lord Pitmedden, Treatise of Mutilation and Demembration and their Punishments, in Sir George MacKenzie, Matters Criminal, (2nd Ed.) (Edinburgh: Andrew Anderson, 1699), pp 21-22 (§64)

${ }^{39}$ Sub Nom Re Organ Retention Litigation [2004] EWHC

${ }^{40}$ See $R v$ Kelly [1999] QB 621

412006 SLT 889

${ }^{42}$ Pollock v Workman (1900) SLT 338 (IH, (2 Div.)); Conway v Dalziel (1901) 9 SLT 85 (IH (1 Div.)); Hughes v Robertson 1913 SC 394 (IH (1 Div.))

43 "Final Report" of the Independent Review Group on Retention of Organs at Post-Mortem (Nov 2001) (available at http://www.show.scot.nhs.uk/scotorgrev/), para.9

${ }^{44}$ See note 43, Final Report, para.14

${ }^{45}$ See note 1, Foster, 2014, p.417

${ }^{46}$ Niall R. Whitty, Rights of Personality, Property Rights and The Human Body in Scots Law, [2005] Edin. L. R 194, pp.235-236

${ }^{47}$ See note 46, Whitty, 2005, pp.235-236

${ }^{48}$ John Blackie, Unity in Diversity, in Niall R. Whitty and Reinhard Zimmerman, Rights of Personality in Scots Law: A Comparative Perspective, (Dundee: DUP, 2009), p.38

${ }^{49}$ See note 38, Pitmedden, 1699, pp 21-22 (§64)

${ }^{50}$ See note 42

${ }^{51}$ The Common law tradition itself has the capacity to recognise the indefinable nature of this wrongdoing using the language of 'dignity' - in the case of Larson v Chase, the Supreme Court of Minnesota recognised that such wrongs are to be considered actionable: "it would be a reproach to the law if a plaintiff's right to recover for mental anguish, resulting from the mutilation or other disturbance of the remains of his dead, should be made to depend upon whether, in committing the act, the defendant also committed a technical trespass upon plaintiff's premises, while everybody's common sense would tell him that the real and substantial wrong was not the trespass on the land, but the indignity to the dead" per Mitchell J., Larson v Chase (1891) 47 Minn. 307

${ }^{52}$ See D.47.10.1.4-6

${ }^{53}$ Bankton, Institute, I, 10, 29

${ }^{54} 19473$ SA $713(0)$

5519483 SA $982(\mathrm{~T})$

${ }^{56}$ See Imogen Jones, A Grave Offence: Corpse Desecration and the Criminal Law, [2017] Leg. Stud. 599, pp.599601

${ }^{57} R$ v Sephuma 19483 SA 982 (T), p.383

${ }^{58}$ See Andrew Christison and Shannon Hoctor, Criminalisation of the Violation of a Grave and the Violation of a Dead Body, [2007] Obiter 23, pp.35-36

${ }^{59}$ Gerhard Kemp (Ed.), Criminal Law in South Africa, (2 ${ }^{\text {nd }}$ Ed.) (Oxford: OUP, 2016)

${ }^{60}$ See J. R. Midgley and J. C. Van Der Walt, Principles of Delict, (4 ${ }^{\text {th }}$ Ed.) (LexisNexis, 2016) 
${ }^{61}$ S v Sewaya 2004 (1) SACR 387 (T); S v Hoho 2009 (1) SACR 276 (SCA). This assertion may be questioned as it does not appear to be an aspect of all cases of crimen injuria: See note 24, Burchell, 2009, fn.15

${ }^{62}$ See note 58, Midgely and Van Der Walt, 2009, pp.35-36

${ }^{63}$ See note 58, Midgely and Van Der Walt, 2009, pp.35-36

${ }^{64}$ For instances of crimen iniuria in South Africa and Namibia, see (e.g.,) Ieperen $v$ The State [2016] A194/2016 (South Africa) Joseph Shonale v The State CA 61/2016 (Namibia)

${ }^{65}$ H.M Advocate v Devlin [2004] GWD 285

${ }^{66}$ See Jonathan Brown, Res Religiosae and the Roman Roots of the Crime of Violation of Sepulchres, [2018] Edin. L.R 347

${ }^{67}$ Dig.47.12, Cod.9.19

${ }^{68}$ See note 13, Iniuria and the Common Law, p.13

${ }^{69}$ Indeed, significant doctrines have previously been introduced to English law by means of Scottish cases: Consider the infamous Donoghue v Stevenson [1932] UKHL 100

${ }^{70}$ See note 13, Iniuria and the Common Law, p.1

${ }^{71}$ See Francois du Bois, Harassment: A Wrong Without a Right, in Eric Descheemaeker and Helen Scott, Iniuria and the Common Law, (Oxford and Portland, Oregon: Hart, 2013), passim.

${ }^{72}$ S.C Smith, When the Truth Hurts, [1998] Scots Law Times (News) 1, p.5

${ }^{73}$ Reinhard Zimmermann, Actio Iniuriarum, in The Law of Obligations: Roman Foundations of the Civilian Tradition, (Oxford: Clarendon Press, 1996), p.1092 